\title{
Anti-mutagenic Action of Ruta chalepensis against Rat Sperm Cell Abnormalities-induced by Potassium Bromate
}

\author{
Nagat S. Elhaddad ${ }^{1^{*}}$, Eman M. Efkerine ${ }^{2}$, Hoda A. Khatab ${ }^{1}$, \\ Ibrahim S. Eldurssi $i^{3}$ and Eman M. Belkasem ${ }^{1}$ \\ ${ }^{1}$ Department of Botany, Faculty of Science, University of Omer Al-Mukhtar, Al-Baida, Libya. \\ ${ }^{2}$ Department of Zoology, Faculty of Education, University of Omer Al-Mukhtar, Al-Baida, Libya. \\ ${ }^{3}$ Department of Zoology, Faculty of Science, University of Omer Al-Mukhtar, Al-Baida, Libya.
}

\section{Authors' contributions}

This work was carried out in collaboration among all authors. Authors ISE and NSE designed the experiment. Authors NSE and HAK were responsible for the experimental procedures. Author EME was the main responsible for the application of the experiment and statistical analysis. Author EMB was in collaboration with author EME throughout this work. Authors NSE, EME and HAK had the main responsibility for writing and all authors read and approved the final manuscript.

Article Information

DOI: $10.9734 / A R R B / 2020 / v 35 i 230187$ Editor(s):

(1) Dr. Manikant Tripathi, Dr. Ram Manohar Lohia Avadh University, India. Reviewers:

(1) Merghem Mounira, Ferhat Abbas University, Algeria. (2) Christopher Chiedozie Mbadugha, University of Uyo, Nigeria. Complete Peer review History: http://www.sdiarticle4.com/review-history/54933

Original Research Article

Received 24 December 2019

Accepted 29 February 2020

Published 08 April 2020

\section{ABSTRACT}

Aims: The aim of current study was to investigate the genotoxic damage of potassium bromate on sperm cell morphology and the potential defense role of Ruta chalepensis (Rue) against the potassium bromate effects.

Study Design: Fifty rats (Strain: Rattus norvegicus) were randomly divided into five groups (10 rats/group) as follows: (Control group) received distilled water daily for 4 weeks, $\left(\mathrm{KBrO}_{3}\right.$ group) treated with $\mathrm{KBrO}_{3}(100 \mathrm{mg} / \mathrm{kg} / \mathrm{b} . \mathrm{w})$ for 4 weeks, (Rue group) received Rue orally in a daily dose ( $0.5 \mathrm{~g}$ /animal) for 4 weeks, (treatment group) were first provided with oral doses of $\mathrm{KBrO}_{3}$ daily for 2 weeks and then treated orally with $\mathrm{KBrO}_{3}$ in association with Rue for an additional 2 weeks Finally (protective group) was administered with Rue orally for 2 weeks and then administered oral doses of Rue in association with $\mathrm{KBrO}_{3}$ for an additional 2 weeks. 
Place and Duration of Study: Department of Zoology and Department of Botany, University of Omar Almukhtar, between July 2018 and September 2019.

Methodology: Sperm suspensions, filtered and smears were made according to the standard protocol for sperm morphology assay. The smears were fixed, allow to dry and stained with hematoxylin and then washed under slow running water until the excess stain is removed and were putted in eosin dye.

Results: The results were showed that potassium bromate has the ability to cause mutations in the morphology of sperm cells. The highest mutation rates of head, tail and neck reached 16.60, 5.200 and 3.200 respectively in animals. Several types of sperm abnormalities such as hock free, banana type, amorphous, hummer shape after the administration of potassium bromate comparing with the negative control animals that treated only with potassium bromate. On the other hand, the oil extract of Ruta chalepensis significantly inhibited the mutations by declining the abnormality rates of head, tail and neck to $2.600,1.600$ and 0.400 in protective group. Thus, potassium bromate has to be considered as a conceivable line regarding human health.

Conclusion: Potassium bromate clearly caused a wide range of sperm cell abnormalities and Rue oil extracts have a good anti-mutagenic effects against potassium bromate by decreasing the sperm cell abnormalities.

Keywords: Mutation; sperm cell; potassium bromated; Ruta chalepensis; anti-mutagenic.

\section{INTRODUCTION}

Food additives are the substances that added to food in order to prolong the life expectancy of the industrial food by inhibiting the development of microorganisms such as bacteria and fungi. Some other purposes including coloring, flavoring, sweetening and thickening are also targeted of the food additives. About 5000 trade name products on a worldwide-basis for about 2500 chemicals that function as food additives [1]. World Health Organization (WHO) together with Food and Agriculture Organization (FAO) defined the food additives as any substances that are added to food to maintain or improve the safety, freshness, taste, texture [2]. Potassium bromate $\left(\mathrm{KBrO}_{3}\right)$ is one of the chemicals that are extensively used as a food additive. Abundantly of countries, mainly in South East Asia are using potassium bromate as flavor enhancer in food products. Potassium bromate is a chemical additive mixed in flour to improve the dough, rising the volume of the bread and hold its shape, subsequently, humans are daily exposed to these chemical substances $[3,4]$. It has been estimated that about $75 \%$ of the Western diet is made up of various processed foods, each person is now consuming an average 8-10 lbs of food additives per year, with some possibly eating considerably more $[5,6]$. With the great increase in the use of food additives, there also has emerged considerable scientific data linking food additive intolerance with various physical and mental disorders, particularly with childhood period $[7,8]$. To reduce the harmful effects of exposure to those food additives, human may be enhancing their consumption of medicinal plants that having a wide medical and traditional usage. Many studies were demonstrated that the extractions of a range of medicinal plants are having an antioxidant, antibacterial, antimicrobial, antiparasitic, anti- mutagenic, antifungal and anticarcinogenic properties [9-13]. In recent years, the interest of using herbal drugs to treat different diseases has been improved and also the World Health Organization (WHO) has recommended evaluation of the efficiency of medical plants when required [14]. Because of high cost and the range of side effects may have caused by taking synthetic drugs, alternative medicine became necessary. In general, plants including fruits and vegetables are rich in antioxidants such flavonoids and phenolic compounds [15]. These phytochemicals were proven to be effective against various mutagens either through scavenging free radicals or by their reducing power [16].

Ruta chalepensis (Rue) is a Libyan local plant that has been widely used as a medicinal plant and it is one of a member of Rutaceae family [17]. It's leaves and young stems have been reported to contain alkaloids, flavonoids, phenols, amino acids, furanocoumarins and saponins [18].

In recent years, there has been a resurgence of interest to rediscover medicinal plants as a source of potential drug candidate. Therefore, scientists should aim to understand the knowledge of the medicinal plants as a future 
source of herbal drugs. Our objective in current study is evaluating the genotoxic effects of potassium bromate on the abnormalities of sperm cell morphology and counting in rat and then examine the potential anti-genotoxic and the protective action of ruta against potassium bromate.

\section{MATERIALS AND METHODS}

\subsection{Experimental Animals}

Fifty adult male albino rat (Rattus norvegicus), free from any observable ailment, obtained from the University of Cairo, Egypt, the rats were then transfer to the animal house for Zoology Department University of Omar AL-Mukhtar. Wood shavings was collected from sawmill and used for beddings, the beddings were changed at least twice per week throughout the period of the experiment. A standard laboratory conditions were maintained under (temperature between $21-25^{\circ} \mathrm{C}$ and a 12 -hour light/12 dark cycle). The rats were left for two weeks as an adaptation period and was given a special diet, all rats received food and water with fresh supplies presented daily. Their weights ranged between 275-300 g at the commencement of the experiment.

\subsection{Potassium Bromate}

Potassium bromate salt, a product of British drug home limited, was supplied in its white crystalline powder or granules form by BDH chemicals Ltd Poole England; CAS No.7758-01-2, name Bromic acid, potassium salt and IUPAC systematic name potassium bromate. Molecular formulae $\mathrm{KBrO3}$, relative molecular mass (167.00). Potassium bromate was orally administrated at a dose of $100 \mathrm{mg} / \mathrm{kg} / \mathrm{b} . \mathrm{w}$. dissolved in distilled water freshly prepared [19] daily for 2 and 4 weeks according to the group distribution.

\subsection{Plant}

Ruta chalepensis L. (Rue) is an aromatic evergreen shrub,one of the plants that belongs to Rutacease family and has shown to have remarkable medicinal properties and is considered as an important remedy for a number of ailments in many systems of medicine. It is native to the Mediterranean and is current distributed worldwide [20]. It was administered by oral gavage route in specific dose. The collected flowers and leaves were weighed, washed carefully with tap and then distilled water, dried using filter papers and then placed in acetone inside sealed jars for 48 hrs. Solvent was removed from samples by Rotary Evaporator and then oil was collected. $R$. chalepensis was at dose of $0.5 \mathrm{~g} /$ Animal [21] daily for 2 and 4 weeks, which represents the overall experimental duration. Both doses were orally given through a special stomach tube with a smooth tip to protect the interior lining of the oral and buccal cavity from injury.

\subsection{Experiment Design}

After acclimatization, animals were divided into five main groups (Groups I-V) and housed in five cages; each containing ten rats, the rats were randomly selected and marked by tail painting to permit individual identification. The tested substance was administered in a single oral dose by gavage using suitable cannula. The rats were weighed and then dose was calculated according to the body weight.

Group I: Negative control rat received only the standard diet and distilled water for 4 weeks. Group II: rat received potassium bromate $\mathrm{KBrO}_{3}$ for 4weeks. Group III: rat of this group received $R$. chalepensis oil at dose of $0.5 \mathrm{mg} / \mathrm{rat}$ for 4 weeks. Group V: treatment group administration of $\mathrm{KBrO}_{3}$ daily primarily for 2 weeks then given of $\left(\mathrm{KBrO}_{3}\right)+R$. chalepensis oil extract daily for 2 weeks. Group IV: Protective Group This group were divided into two stages; given $R$. chalepensis oil extract primarily for 2 weeks followed by $R$. chalepensis oil extract $+\mathrm{KBrO}_{3}$ for 2 weeks.

\subsection{Sperm Morphology Assay}

After opening the abdominal cavity being careful to not cut into the viscera, testes and cauda epididymis were removed. Sperm suspensions were prepared by mincing cauda in $2 \mathrm{ml}$ of phosphate buffered saline (PBS, $\mathrm{pH}=7.2$ ), were filtered, and smears were made according to the standard protocol for sperm morphology assay. Slides were coded for analysis and suspension was placed on the clean slide. The smears were fixed in $75 \%$ methanol: $25 \%$ acetic acid, the slides allow to dried on hot plate, stained with hematoxylin for $15 \mathrm{~min}$. After that the slide were washed under slow running water until the excess stain is removed and then were putted in eosin stain for $10 \mathrm{~min}$. The slides 
were washed with ethanol and allowed them to dry on hot plate again. Slides were observed for sperm shape abnormality under light microscope [22].

\subsection{Statistical Analysis}

The data obtained were subjected to one-way analysis of variance (ANOVA). Using Mintab statistical package program (Mintab version 17). The group means were separated by Tukey's test at $\mathrm{P}<0.05$. Results were presented as mean \pm standard error of mean (SEM).

\section{RESULTS AND DISCUSSION}

\subsection{The Effect of Potassium Bromate and the Extract of $R$. chalepensis on Abnormal Sperm Counting}

This experiment was designed to investigate the mutagenic effects on the susceptibilities of male germ cells alteration in the number after exposure to potassium bromate. Results were achieved by viewing slides under a microscope at high magnifications, photomicrographs were occupied using a microscopic digital camera. Table 1 shows the sperm analysis results after 30 days administration of the treatments.

Data recorded in the table are presenting the number of sperm shape mutations in all of the head, tail and neck. Control rats showed constant levels during the course of the study without any spontaneous mutation with zero mean values of the three investigated parameters (head, tail and neck). In general, the highest sperm cells morphology mutations were gained in all of different exposed types was the head mutation followed by tail mutation and the least mutation in this study was in neck morphology. High significant differences $(P<$ 0.000 ) between control and $\mathrm{KBrO} 3$ treated group were achieved, $16.60,5.20$ and 3.20 are the averages for head, tail and neck respectively. Mean values (head: 4.400, tail: 2.00 and neck: 1.60) of treatment group were high significantly different $(P<0.005)$ when compared to nontreated animals but still less significant than potassium bromate exposed animals. However, no significant differences were found in the all of parameters were assessed between control rats and those exposed to R.chalepensis extract. The difference between non-treated group and protective group is considered to be statistically significant for the head counting (2.600) at $\mathrm{P}<0.005$ and for tail. (1.600) at $\mathrm{P}<0.005$, whereas there were no significant differences at the level of the neck mutations where the mean value decreased to 0.400 .

\subsection{The Effect of Potassium Bromate and R. chalepensis on Sperm Morphology}

The results that obtained by assessing the sperm morphology mutations are presented in (Fig. 2) which illustrates different types of sperm abnormalities comparing with the negative control animals (Fig. 1).

\subsubsection{Control group}

Normally, the head of the rat sperm resembles a hook, contains a dense nucleus and has a less dense tip referred to as the acrosome. The midpiece contains the centrioles and a spirally coiled sheath of mitochondrial material. The tail contains a long axial filament that becomes vibratile for a brief period when the spermatozoon is mature. It should be noted that occasionally the centriole may be visible, and is seen approximately halfway along the tail and should not be noted as an abnormality.

Fig. 1 reveals the normal sperm shape of the rat in this study. At the magnification generally used for assessment of sperm morphology it was difficult to distinguish the mid -piece. Also few abnormalities of the mid-piece have been reported for rat sperm. Hence, it will not be dealt with separately, but included as part of assessment of the sperm tail.

\subsubsection{Potassium bromate $\left(\mathrm{KBrO}_{3}\right)$ group}

Rats belonging to the group orally received a daily dose of $\mathrm{KBrO}_{3}(100 \mathrm{mg} / \mathrm{kg})$ for four weeks. Examination of the sperm of $\mathrm{KBrO}_{3}$ treated rats revealed that potassium bromate caused mutations in the sperm morphology in comparison with the control animals.

Fig. 3 shows multiple abnormalities in sperm head and tail such as hock free, banana type, amorphous, hummer shape after the administration of potassium bromate.

These results indicated that potassium bromate induced these sperm head abnormalities in this group whereas no abnormalities were noticed in control rats. Reduced hook or banana head were demonstrated in (Fig. 3), this can be seen as varying degrees of reduced curvature of the head 
with occasionally complete absence of curvature. (Fig. 3) showed decapitated or detached head that seen as a head without tail. Free heads are usually seen in a sperm smear but are not counted unless a tail and head are seen together.

Table 1. The sperm count analysis of control and treated animals. All data are expressed as mean \pm standard error (SE). Five rats in each group

\begin{tabular}{|c|c|c|c|c|c|}
\hline $\begin{array}{l}\text { Groups } \\
\text { Parameters }\end{array}$ & $\begin{array}{l}\text { Control } \\
\text { Mean } \pm \text { SE }\end{array}$ & $\begin{array}{l}\text { KBrO3 } \\
\text { Mean } \pm \text { SE }\end{array}$ & $\begin{array}{l}\text { Rue } \\
\text { Mean } \pm \text { SE }\end{array}$ & $\begin{array}{l}\text { Treatment } \\
\text { Mean } \pm \text { SE }\end{array}$ & $\begin{array}{l}\text { Protective } \\
\text { Mean } \pm \text { SE }\end{array}$ \\
\hline Head & $0.0 \pm 0.0$ & $16.60 \pm 1.72^{\star \star \star}$ & $1.200 \pm 0.583$ & $4.400 \pm 0.510^{\star *}$ & $2.600 \pm 0.510^{\star *}$ \\
\hline Tail & $0.0 \pm 0.0$ & $5.200 \pm 0.860^{\star \star *}$ & $1.300 \pm 0.510$ & $2.000 \pm 0.707^{\star *}$ & $1.600 \pm 0.510^{*}$ \\
\hline Neck & $0.0 \pm 0.0$ & $3.200 \pm 0.583^{\star * *}$ & $0.800 \pm 0.374$ & $1.600 \pm 0.510^{*}$ & $0.400 \pm 0.245$ \\
\hline
\end{tabular}

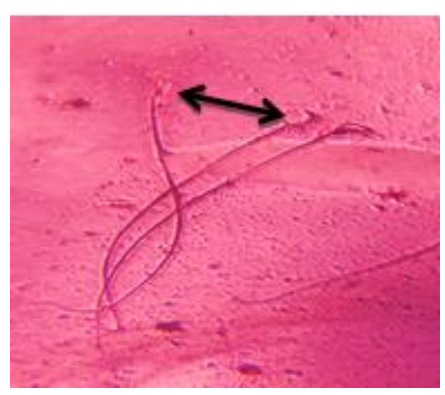

Fig. 1. Photomicrograph of normal sperm head and tail of control rats (Hematoxylin \& Eosin stain, 40X)
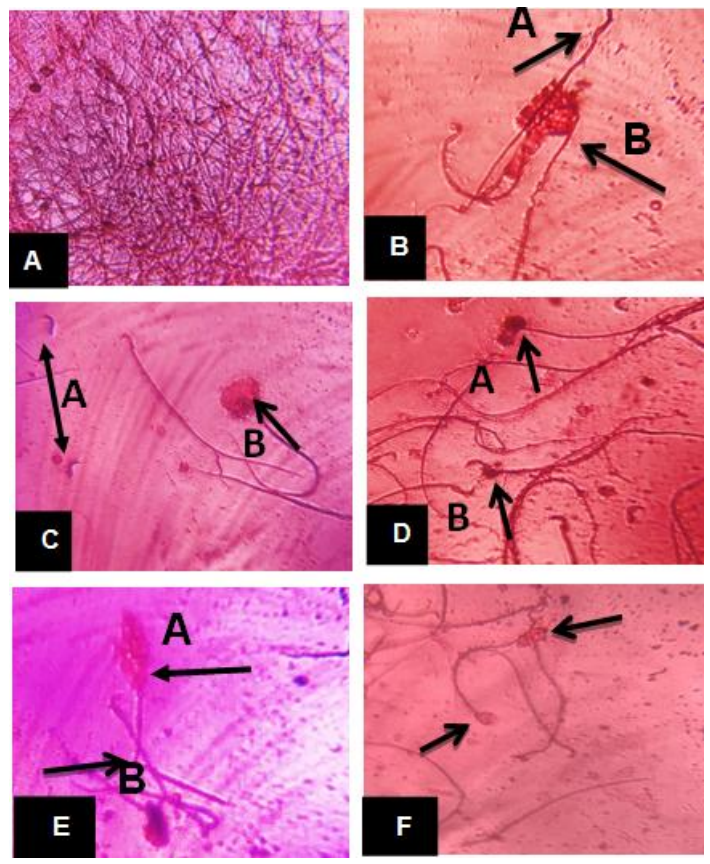

Fig. 2. Photomicrographs show sperms of rat treated daily with $\mathrm{KBrO} 3(100 \mathrm{mg} / \mathrm{kg})$ for 4 weeks with abnormal heads and tail (Hematoxylin \& Eosin, X 40).(A) fusion sperm,( B) two abnormal heads ; (a) Banana shape;(b) Amorphous) .(C);(a) detached sperm heads ,(b) Amorphous).(D);

(a) double abnormal heads with one tail, (b) sperm with mis-shappen head (Hook at wrong angle). (E);(a) Long amorphous head, (b) irregular tail (bent tail), (F) Round heads with abnormal mid-piece 


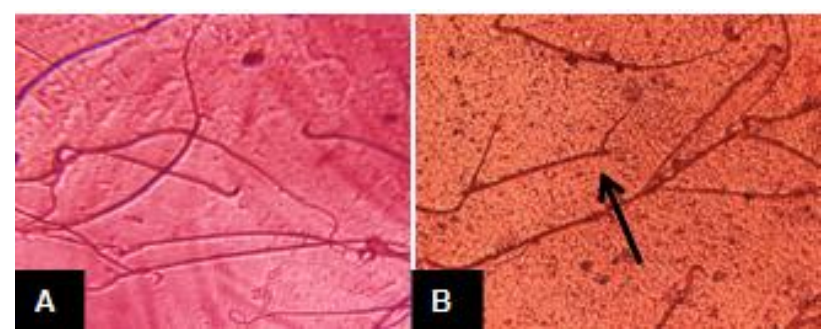

Fig. 3. Photomicrograph of sperm rat treated daily with Rue $(0.5 \mathrm{~g} / \mathrm{Animal})$ for 4 weeks, (A)showing normal sperm; (B) abnormality shapes of sperm; irregular tail (Hematoxylin \& Eosin 40X)

\subsubsection{R. chalepensis group}

Rats belonging to this group orally gave a daily dose of Rue ( $0.5 \mathrm{~g} / \mathrm{Animal})$ for four weeks; by a light microscope, under a magnification of $40 \mathrm{X}$ slides were assessed for any abnormality in tail, neck or head. The assessment showed in (Fig. $4-\mathrm{A}$ ) revealed that the majority of the sperm were all normal and almost similar to that results where demonstrated by the control group. Fig. (4-B) shows one type of sperm abnormality which was irregular tail (bent tail).

\subsubsection{Treatment group}

Rats received oral dose of $\mathrm{KBrO} 3$ (100 $\mathrm{mg} / \mathrm{kg} / \mathrm{b} . \mathrm{w}$ ) daily for two weeks then administered additional oral dose of both $\mathrm{KBrO} 3$ (100 $\mathrm{mg} / \mathrm{kg} / \mathrm{b} . \mathrm{w})$ and Rue (0.5 g/Animal) for another two weeks. At the end of experimental duration of 4 weeks, data showing an improvement of sperm morphology to ward control animals after administration of oil extract in comparison to potassium bromate rats (Fig. 5).

\subsubsection{Protective group}

Rats belonging to this group received oral doses of Rue ( $0.5 \mathrm{~g} /$ Animal) daily for 2 weeks followed by oral treatment with Rue at a dose of $(0.5$ $\mathrm{g} /$ Animal) and $\mathrm{KBrO}_{3}(100 \mathrm{mg} / \mathrm{kg} / \mathrm{b} . \mathrm{w})$ for another 2 weeks. Fig. 6 revealed approximately normal appearance of the sperm morphology compared with $\mathrm{KBrO}_{3}$-treated group. Rats in the protective group revealed an almost regular features of sperm morphologies. There were minimal changes in shape, both head and tail gained partial near to normal features.

Nowadays, food additives are major problems encountered in the food industry. All food additives should be assessed to test their short and long term genetic and toxic effects which have not been fully under control yet. These resemble a major importance for our health as result of daily taken food additives through food and can be accumulated inside the body throughout life due to the very long exposure. Different studies have indicated that $\mathrm{KBrO}_{3}$ was found to be genotoxic and carcinogenic effects in both human and experimental animal. Recently different Short-term genotoxicity testing assays are used to evaluate the genotoxic damage of $\mathrm{KBrO}_{3}$. Medicinal plants products are rich in secondary metabolites and essential oils with therapeutic use, which investigate therapeutic action of various medicinal plants as natural antioxidants to cure chronic diseases such as DNA damage, mutagenesis and carcinogenesis.

The spermatozoa morphology test is a reliable parameter to characterize different chemical germ cell toxicity and genotoxicity. The present study assessed the effect of both potassium bromate and ruta oil extract on mutation of sperm morphology of male rats. Table 1 shows the effect of the four parameters (potassium bromide, ruta extract, treatment and protective group) compared to control. The number of malformations in the sperm form of rats treated with potassium bromide as well as treatment group was high and both had significant differences compared with control. Less significant differences in protective group while there were no significant differences between control and the ruta group. Genotoxic substances are potential inductors of sperm cells morphology alterations because they could modify the normal process of gametogenesis. This process is not independent and is regulated by complex mechanisms under polygenic control. Any qualitative or quantitative modification in the above-mentioned characteristic that can be associated with nutrition, pharmacological or environmental changes, may be considered a good bio indicator of genetic damage. This is the 
case of the present research, where the effects of the administration of a food additive, potassium bromate doses to male rats were studied in terms of mutations in sperm cells morphology.

It was reported that the treatment of potassium bromate resulted in marked increase in free radicals activities [23]. The uncontrolled production of free radicals could possibly be lead to carcinogenesis [24,25]. The alteration in sperm parameters could be attributed to direct effect on testicular tissue which leads to reproductive dysfunction such as reduced sperm count, motility and morphology [26]. Elsheikh, et al. [27] showed that $\mathrm{KBrO}_{3}$ supplementation to drinking water retarded the growth in growing rats and consequently reduced the testicular and epididymal weights. Furthermore, exposure to $\mathrm{KBrO}_{3}$ alters the histology of the rat testis and impaired spermatogenesis.

Our results suggest that potassium bromate administration significantly increase sperm morphological abnormalities. These findings were similar to data from [28] that showed after 5 daily erythrosin, a food colorant, administration at dose of 680 and $1360 \mathrm{mg} / \mathrm{kg}$ affect the count and motility of epididymis sperm and increased the incidence of sperms with abnormal head. Tartrazine, orange-colored widely used in food products, drugs and cosmetics, was administered to adult male mice in drinking water at different doses for 13 weeks. After that period, some parameters were determined. The sperm count was decreased and sperm abnormalities were increased in the tartrazine treated groups compared to the control [29]. These show that synthetic food additive may affect the reproductive function. During the process of spermiogenesis, if the pre-meiotic, meiotic or post-meiotic spermatogenic cells are exposed to a mutagenic agent which interfere with DNA, genetic damage may be expressed as abnormal sperm or other phenotypic expressions. The formation of sperm heads involves a complex series of morphological and biochemical events. During the process of spermiogenesis, sperm may develop abnormally. The most reasonable mechanisms for the production of sperm head abnormalities are small deletions or point mutations $[30,31]$. It was also assumed to be a result of an abnormal chromosome [32]. Another two studies $[33,34]$ reported that abnormalities in sperm heads may occur by physiological, cytotoxic or genetic mechanisms or alterations in testicular DNA which in turn disrupts the process of differentiation of spermatozoa [35].

Various of gene mutation that lead to changes of sperm morphology have been reported. AURKC is a member of serine/threonine protein kinases and is a component of the chromosomal passenger complex (COC) which is an essential regulator of mitotic events, including chromosome segregation and cytokinesis.
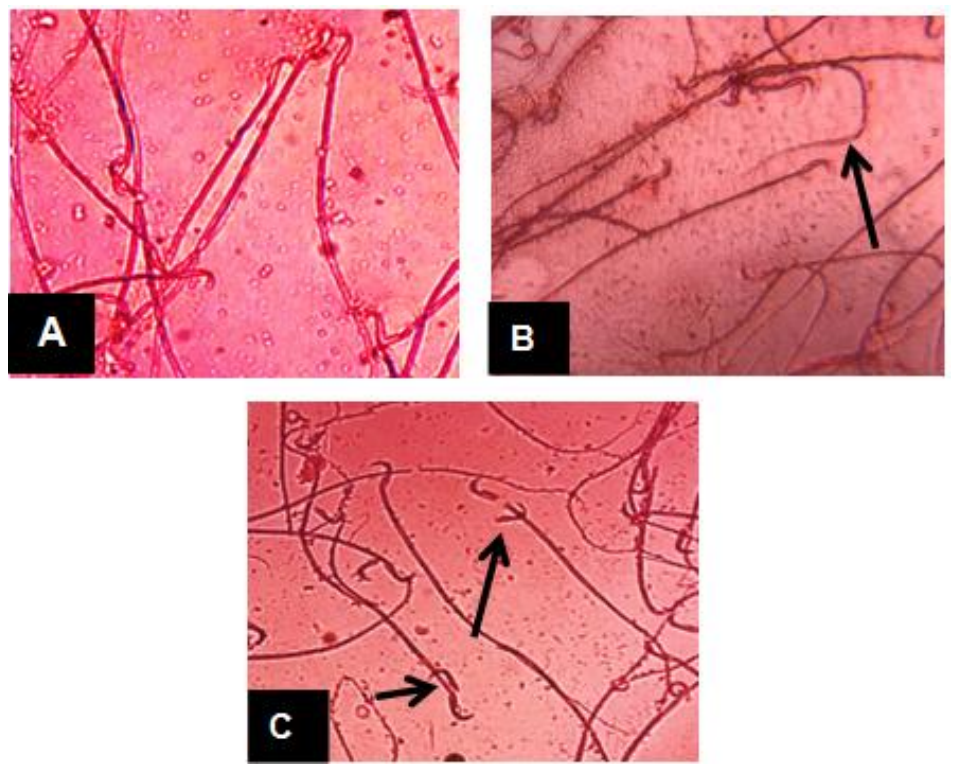

Fig. 4. Photomicrograph of sperm rat of treatment group after 4 weeks; (A) showing normal sperm; (B) tail without head; (C) head without tail (Hematoxylin \& Eosin, 40X) 

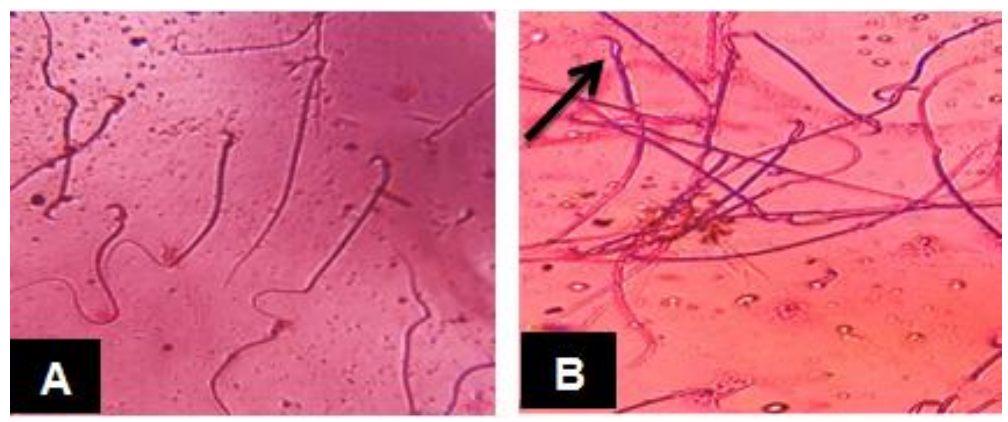

Fig. 5. Photomicrograph of sperm rat from protective group after 4 weeks. A: sperm near to normal features. B: Abnormal sperm (hairpin-like) (Hematoxylin \& Eosin, 40X)

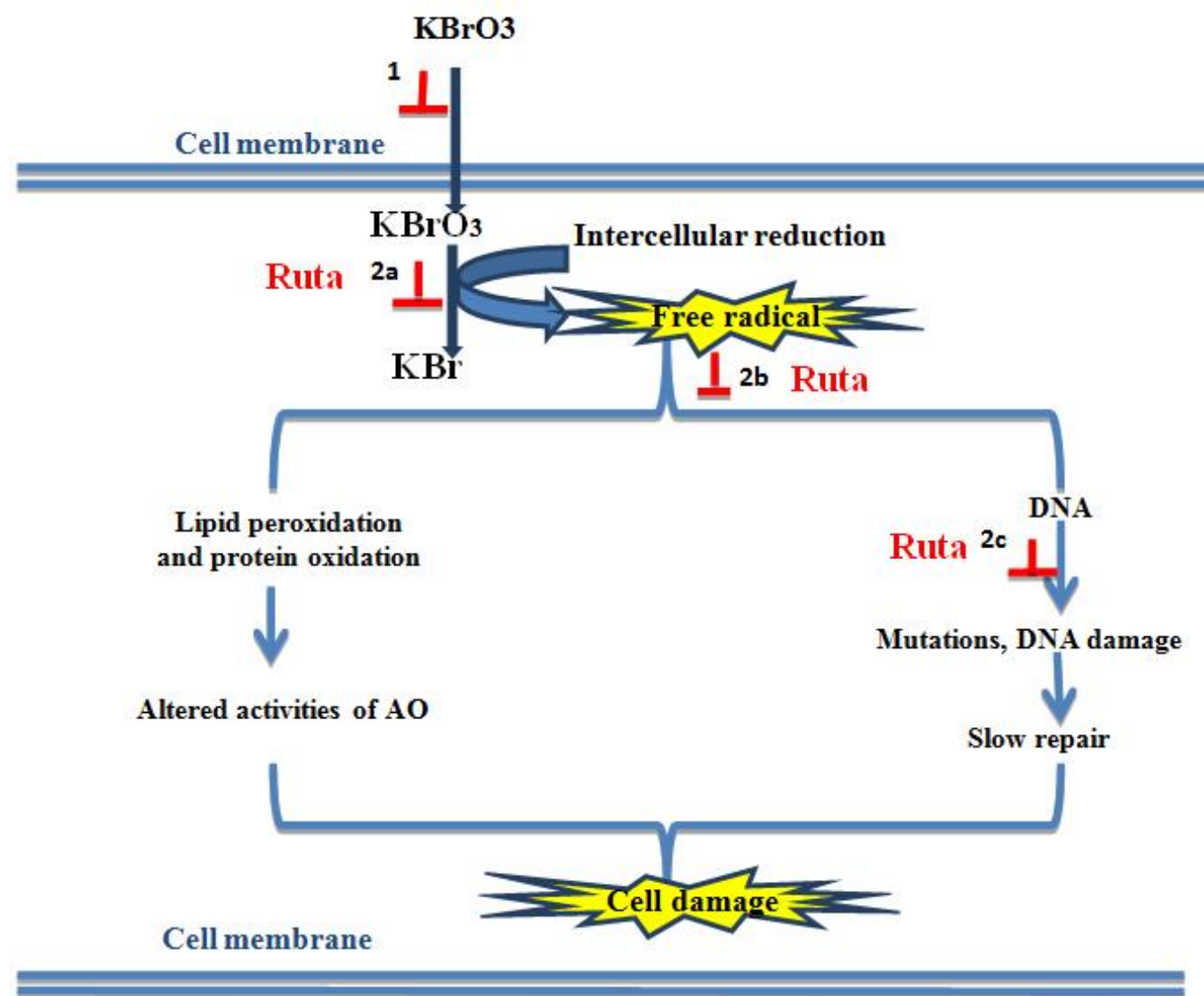

Fig. 6. Proposed diagram for the antimutagenic action of $\boldsymbol{R}$. chalepensis

Results represented above suggested that fixed oil extract of ruta maybe has the ability to inhibit the mutagenic impact of potassium bromate in several positions: 1- Out the cell by blocking receptors. 2- In site the cell: (a) Ruta may reacts with potassium bromate $\mathrm{KBrO} 3$ and convert it into harmless compounds. (b) Antioxidant action against potassium bromate free radical. (c) Induction of DNA -damage response proteins. The diagram modified from [40]

Defects of the AURKC protein lead to disruptions in meiosis and to chromosomally unbalanced gametes [36] resulting in polyploidy sperm cells with enlarged and irregular shaped heads and multiple flagella. SPATA16 is localized at the Golgi apparatus and plays an essential role in the acrosome formation during spermatogenesis. Loss of function of this gene lead to sperm cells with round head and no acrosome $[37,38]$. 
DNAH1 encodes an axonemal inner dynein heavy chain. Mutations in the DNAH1 gene show general axonemal disorganization including mislocalization of the microtubule doublets and loss of the inner arm dyneins. In addition, disorganization of the fibrous sheath, the outer dense fibres and the mitochondrial sheath leading to multiple morphological irregularities of the tail such as absent, bent, coiled and tail of irregular width $[39,40]$.

Fig. 6 reflects the proposed antimutagenic action of $R$. chalepensis in several locations. Medicinal plants were previously classified into two main classes, dismutgencity where plants able to function outside the cell membrane and antimutagencity where plants could be act their roles via multibe positions. In addition to that, some medicinal plants have the ability to work out and inside the cell. Our medicinal plant $(R$. chalepensis) possibly is able to function as both disantimutagenic and antimutagenic. This data presents suggesting mutagenic impacts of potassium bromate and novel antimutagenic roles of $R$. chalepensis.

\section{CONCLUSION}

Results presented in current study indicate that potassium bromate has a potential genotoxic and mutagenic effects. Potassium bromate enhancer flavour clearly caused a wide range of sperm cell abnormalities and may lead to similar cytogenic effects in higher organisms. Rue oil extracts have a good antimutagenic effects against potassium bromate by decreasing the sperm cell abnormalities and increasing their counting toward control data. Current medicinal plant can be considered as promising sources of natural antioxidants for medicinal and commercial uses.

\section{ACKNOWLEDGEMENTS}

Authors would like to thank both of Abdullah Ali Hamed and Gasem Mohammed Atiyah for their wonderful assistance in Rat breeding, feeding and cleaning.

\section{ETHICAL APPROVAL}

As per international standard or university standard written animal ethical approval has been collected and preserved by the author(s).

\section{COMPETING INTERESTS}

Authors have declared that no competing interests exist.

\section{REFERENCES}

1. Ash M, Ash I. Handbook of food additives, (Aldershot: Gower); 1995.

2. World Health Organization. Expert committee on food additives. Seventh report on the specification for the identity and purity of food additives and their toxicological evaluation: Emulsiflers, stabilizers, bleaching and maturing agents. World Health Organization Technical Report. Series 281 Geneva. 1964;164.

3. Chipman J, Davies J, Parsons J, Nair J, O'neill G, Fawell J, DNA oxidation by potassium bromated: A direct mechanism or linked to lipid peroxidation? Toxicology. 1998;126:93-102.

4. Ahmed M, Mahmood R. Protective effect of taurine against potassium bromate-induced hemoglobin oxidation, oxidative stress, and impairment of antioxidant defense system in blood. Environmental toxicology. 2016;3:304313.

5. Miller M. Danger! Additives at Work, London Food Commission. London; 1985.

6. ACARD. The food industry and technology. Cabinet Office. Advisory Council for Applied Research and Development. HMSO. London; 1982.

7. Feingold BF. Food additives and child development. Hospital Practice. 1973;21: 17-18.

8. Smith JM. Adverse reactions to food and drug additives. European J. Clin. Nutr. 1991;45:17-21.

9. Lamaison JL, Freytel C, Carnat A. Rosmarinic acid, total hydroxycinnamic derivatives and antioxidant activity of Apiaceae, Borraginaceae and Lamiaceaemedicinals. Ann-pharm. Fr. 1990;48(2): 103-108.

10. Economou KD, Oreopoulou V, Thomopoulos CD. Antioxidant activity ofsome plant extracts of the family labiatae. JAOCS. 1991;68(2):109-112.

11. Vekiari SA, Orcopoulo V, Tzia C, Thomopoulos CD. Oregano flavonoids aslipid antioxidants. JAOCS. 1993;70(5): 483-487.

12. Dorman HJ, Deans SG. Antimicrobial agents from plants: Antibacterial activity of 
plant volatile oils. J Appl Microbiol. 2000; 88(2):308-316.

13. Exarchou $V$, Nenadis $N$, Tsimidou $M$, Gerothanassis IP, Troganis A, Boskou D. Antioxidant activities and phenolic composition of extracts from Greek oregano, Greek sage and summer savory. J Agric Food Chem. 2002;50(19):52945299.

14. Ayyanar M, Sankarasivaraman $\mathrm{K}$, Ignacimuthu S. Traditional herbal medicines used for the treatment of diabetes among two major tribal groups inSouth Tamil Nadu. India. Ethnobotanical Leaflets. 2008;12: 276-280.

15. Luximon-Ramma A, Bahorun T, Crozier A. Antioxidant actions and phenolic and vitamin C contents of common Mauritian exotic fruits. Journal of the Science ofFood and Agriculture. 2003;83(5):496-502.

16. Akinboro A, Mohamed KB, Asmawi M.Z, Sofiman OA. Mutagenic and antimutagenic potentials of fruit juices of five medicinal plants in Allium cepa L. Possible influence of DPPH free radical scavengers. African Journal of Biotechnology. 2011; 10(51):10520-10529.

17. Jafri SMH. Flora of Libya, Rutaceae. AlFaath University. Faculty of Science, Department of Botany. Tripoli. 1977;2-4.

18. Kacem M, Kacem I, Simon G, Mansour A.B, Chaabouni S, Elfeki A, Bouaziz M. Phytochemicals and biological activities of Ruta chalepensis L. growing in Tunisia. Food bioscience. 2015;12:73-83.

19. Ukoha UU, Okafor JI, Udemezue OO, Ndukwe GU, Udenwogu CJ. The histological effect of potassium bromate on the cerebellum of adult wistar rats. Inter. J. Health Sci. Res. 2014;4:114-118.

20. Akkaria H, Ezzineb O, Dhahri S, B'chir F, Rekik M, Aziz HS, et al. Chemical composition, insecticidal and in vitro anthelmintic activities of Ruta chalepensis (Rutaceae) essential oil. Ind Crop Prod. 2015; 74:745-751.

21. AL-Qarawi AA. Stimulatory effect of the aqueous extract of Ruta chalepensis on the sex organs and hormones of male rats. J Appl Res. 2005;5:206-211.

22. Evans E, Breckon G, Ford C. An air-drying method for meiotic preparations from mammalian testes. Cytogenetic and Genome Research. 1964;3:289-294.

23. Uemeura T, Sai K, Takagi A, Hasegawa R, Kurokawa Y. A possible role for oxidative stress in potassium bromate $\left(\mathrm{KBrO}_{3}\right)$ carcinogenesis. Carcinogenesis. 1995;16: 593-597.

24. Kurokawa Y, Aoki S, Matsushima Y, Takamura N, Imazawa T, Hayashi $\mathrm{Y}$. Dose-response studies on the carcinogenicity of potassium bromate in F344 rats after long-term oral administration. Journal of the National Cancer Institute. 1986;77:977982.

25. Sai K, Tyson CA, Thomas DW, Dabbs JE, Hasegawa R, Kurokawa Y. Oxidative DNA damage induced by potassium bromate in isolated rat renal proximal tubules and renal nuclei. Cancer letters. 1994;87:1-7.

26. De Souza Predes F, Diamante M.A, Dolder $\mathrm{H}$. Testis response to low doses of cadmium in Wistar rats. International Journal of Experimental Pathology. 2010; 91:125-131.

27. Elsheikh AS, Fadul TF, Aboagla EM, Gameel AA. Effects of potassium bromate on male rat growth and testicular histology. Asian Pacific Journal of Reproduction. 2016;5:376-380.

28. Aziz AA, Shouman SA, Attia AS, Saad S. A study on the reproductive toxicity of erythrosine in male mice. Pharmacological research. 1997;35:457-462.

29. Mehedi N, Ainad-Tabet S, Mokrane N, Addou S, Zaoui C, Kheroua O, Saidi D. Reproductive toxicology of tartrazine (FD and C Yellow No. 5) in Swiss albino mice. American Journal of Pharmacology and Toxicology. 2009;4:130-135.

30. Narayana K, D'souza UJ, Rao KS. Ribavirin-induced sperm shape abnormalities in Wistar rat. Mutation Research/Genetic Toxicology and Environmental Mutagenesis. 2002; 513: 193-196.

31. Wyrobek A, Bruce W. Chemical induction of sperm abnormalities in mice. Proceedings of the National Academy of Sciences. 1975;72:4425-4429.

32. Bruce W, Furrer $\mathrm{R}$, Wyrobek $\mathrm{A}$. Abnormalities in the shape of murine sperm after acute testicular X-irradiation, Mutation Research/Fundamental and Molecular Mechanisms of Mutagenesis. 1974;23:381-386.

33. Agunbiade S, Okonko I, Alimba C, Folarin A, Anugweje K. Effects of a carbonaceous bottling plant effluent on albino mice sperm 
morphology and testes histopathology. Nat Sci. 2012;10:154-60.

34. Odeigah $\mathrm{P}$, Nurudeen $\mathrm{O}$, Amund $\mathrm{OO}$. Genotoxicity of oil field wastewater in Nigeria. Hereditas. 1997;126:161167.

35. Giri S, Prasad S, Giri A, Sharma G. Genotoxic effects of malathion: an organophosphorus insecticide, using three mammalian bioassays in vivo. Mutation Research/Genetic Toxicology and Environmental Mutagenesis. 2002;514: 223-231.

36. Coutton C, Escoffier J, Martinez G, Arnoult C, Ray PF. Teratozoospermia: Spotlight on the main genetic actors in the human. Human reproduction update. 2015;21:455485.

37. Lu L, Lin M, Xu M, Zhou ZM, Sha JH. Gene functional research using polyethylenimine-mediated in vivo gene transfection into mouse spermatogenic cells. Asian Journal of Andrology. 2006;8: 53-59.

38. Xu M, Xiao J, Chen J, Li J, Yin L, Zhu H, et al. Identification and characterization of a novel human testis-specific Golgi protein, NYD-SP12. Molecular Human Reproduction. 2003;9:9-17.

39. Khelifa MB, Cotton C, Zouari R, Karaouzene T, Rendu J, Bidart M, et al. Mutations in DNAH1, which encodes an inner arm heavy chain dynein, lead to male infertility from multiple morphological abnormalities of the sperm flagella. The American Journal of Human Genetics. 2014;94:95104.

40. Ahmed MK, Khan AA, Ali SN, Mahmood R. Chemoprotective effect of taurine on potassium bromate-induced DNA damage, DNA-protein cross-linking and oxidative stress in rat intestine. PloS One. 2015;10: 0119137.

(c) 2020 Elhaddad et al.; This is an Open Access article distributed under the terms of the Creative Commons Attribution License (http://creativecommons.org/licenses/by/4.0), which permits unrestricted use, distribution, and reproduction in any medium, provided the original work is properly cited.

Peer-review history:

The peer review history for this paper can be accessed here: http://www.sdiarticle4.com/review-history/54933 